\title{
KOMPOSISI JENIS-JENIS IKAN LAYANG (Decapterus spp.) BERDASARKAN HASIL TANGKAPAN NELAYAN BAGAN DI TELUK DORERI, KABUPATEN MANOKWARI, PROVINSI PAPUA BARAT
}

\section{Composition of Decapterus spp. Based on Catch of Fisherman in Doreri Bays, Manokwari District, West Papua Province}

Frankly Lahumeten ${ }^{1}$, Roni Bawole ${ }^{2}$, Ridwan Sala ${ }^{2}$ dan Sampari Saneraro Suruan ${ }^{2 *}$

${ }^{1}$ Program Studi Sumberdaya Akuatik, Sekolah Pascasarjana, Universitas Papua, Manokwari ${ }^{2}$ Fakultas Perikanan dan Ilmu Kelautan, Universitas Papua, Manokwari

*suruan.sampari@gmail.com

Ikan layang (Decapterus spp.) merupakan komponen utama dari sumberdaya ikan pelagis kecil yang sering tertangkap oleh nelayan bagan perahu di perairan Teluk Doreri. Namun belum diketahui secara pasti jenis-jenis ikan layang (Decapterus spp.) yang tertangkap oleh nelayan bagan perahu di perairan ini, sehingga dapat berakibat terhadap jenis-jenis ikan layang (Decapterus spp.) secara spesies, sedangkan informasi ini sangat perlu diketahui untuk menunjang pengelolaan jenis-jenis ikan layang (Decapterus spp.) perairan laut Teluk Doreri Kabupaten Manokwari. Tujuan dari penelitian ini adalah untuk mengetahui jenis-jenis ikan layang yang tertangkap oleh nelayan bagan di Teluk Doreri, Kabupaten Manokwari, Provinsi Papua Barat. Penelitian ini dilakukan selama 7 hari di bulan April 2019. Metode yang digunakan dalam penelitian ini adalah metode observasi langsung. Survei dilakukan pada 6 bagan nelayan yang melakukan operasi penangkapan di perairan Teluk Doreri. Analisis data yang digunakan dalam penelitian ini yaitu analisis deskriptif. Berdasarkan hasil yang didapatkan, nelayan biasanya melakukan operasi peangkapan pada 2 lokasi penangkapan, yaitu belakang Pulau Mansinam dan sekitar perairan Anday, dimana ke 2 lokasi ini merupakan target fishing ground nelayan bagan. Hasil identifikasi jenis-jenis ikan layang menunjukan bahwa, dari 6 bagan nelayan yang melakukan penangkapan ikan layang, ditemukan 3 jenis ikan layang (Decapterus spp.) yang sering tertangkap oleh bagan nelayan di sekitar perairan Teluk Doreri, yaitu jenis Decapterus macarellus, Decapterus akaadsi dan Decapterus macrosoma. Diperlukan kajian lebih lanjut dalam menunjang prospek perikanan ikan layang di Teluk Doreri, Kabupaten Manokwari, Provinsi Papua Barat, Indonesia.

Kata kunci : Ikan Layang (Decapterus spp.), Bagan, Teluk Doreri, Manokwari

Abstract

Flying fish (Decapterus spp.) is a major component of small pelagic fish resources that are often caught by boat charters in the waters of Doreri Bay. However, it is not yet known for certain types of flying fish (Decapterus spp.) caught by boat fishermen in these waters, so that it can result in species of flying fish (Decapterus spp.) in species, this information is essential to support the management of species of flying fish (Decapterus spp.) in the waters of Doreri Bay, Manokwari Regency. The purpose of this study was to find out the types of flying fish caught by fishermen in Doreri Bay, Manokwari Regency, West Papua Province. This research was conducted for 7 days in April 2019. The method used in this study was the direct observation method. The survey was conducted on 6 charts of fishermen who carried out fishing operations in Doreri Bay waters. The data analysis used in this study is a descriptive analysis. Based on the results obtained, fishermen usually carry out fishing operations on 2 fishing locations, namely behind Mansinam Island and around Anday waters, where the 2 locations are fishing ground targets for fishers. The results of identification of flying fish species indicate that, of the 6 fisherman charts that carried out fly fishing, there were 3 types of flying fish (Decapterus spp.) which were often caught by fisherman charts around Doreri Bay waters, namely Decapterus macarellus, Decapterus akaadsi, and Decapterus macrosoma. Further studies are needed to support the prospect of elevated fish fisheries in Doreri Bay, Manokwari Regency, West Papua Province, Indonesia.

Keywords: Decapterus spp., Lift nets, Doreri Bay, Manokwari 


\section{PENDAHULUAN}

Ikan layang (Decapterus spp.) termasuk komponen perikanan pelagis yang penting di Indonesia dan biasanya hidup bergerombol dengan ikan lain seperti lemuru (Sardinella sirm), tembang (Sardinella fimbriala, $\quad S$. perforala), kembung (Rastrelliger kanaguaa. R. brachysoma), selar (Canax sp.), dan ekor kuning (Caerio $s p$.). Di perairan Indonesia terdapat 5 jenis yang umum dijumpai yaitu Decapterus lajang, D. russelli, D. macrosoma. D. kurroides, dan D. maruadsi. Kelima jenis tersebut terdapat pula di perairan Maluku (Weber and Beaufort, 1931).

Nama ilmiah ikan layang adalah Decapterus spp. yang terdiri dari dua suku kata yaitu Deca berarti sepuluh dan pteron bermakna sayap. Jadi Decapterus berarti ikan yang mempunyai sepuluh sayap Nama ini dan kaitannya dengan ikan layang berarti jenis ikan yang mampu bergerak sangat cepat di air laut. Kecepatan tinggi ini memang dapat dicapai karena bentuknya seperti cerutu dan sisiknya sangat halus. Weber and Beaufort (1931) menggolongkan ikan layang pada suku Carangidae, bangsa Percomorphi, kelas Pisces, marga Decapterus dan jenis Decapterus spp.

Marga Decapterus ini mempunyai tanda khusus yaitu sebuah finlet yang terdapat di belakang sirip punggung dan sirip dubur, mempunyai bentuk yang bulat memanjang dan pada bagian belakang garis sisi (lateral line) terdapat sisik-sisik berlengir (lateral scute).

Beberapa pakar dari mancanegara dalam penelitiannya mendapatkan jumlah jenis dari marga Decapterus ini di beberapa tempat diantaranya: Weber and Beaufort (1931) menyatakan bahwa marga Decapterus ada empat jenis di daerah Indo-Australia. Smith (1950) menyatakan ada lima jenis di Afrika Selatan. Munro (1955, 1967) menyatakan di Srilanka hanya satu jenis Iainnya; Chan et al. (1974) menyatakan di Samudera Hindia bagian timur dan Samudera Pasifik sebelah barat ada lima jenis, Kalau digabungkan semuanya maka seluruhnya ada delapan jenis yang telah dikenal yaitu : Decapterus lajang, D. maruadri, $D$. macarellus, D. sancmehelenae, dan $D$. puncurus.

Di perairan Teluk Doreri Kabupaten Manokwari, ikan layang (Decapterus spp.) merupakan komponen utama dari sumberdaya ikan pelagis kecil yang sering tertangkap oleh nelayan bagan perahu, namun belum diketahui secara pasti jenisjenis ikan layang yang tertangkap oleh nelayan bagan, sehingga penelitian ini dilakukan untuk mengetahui jenis-jenis hasil tangkapan nelayan bagan di perairan Teluk Doreri, Kabupaten Manokwari, Provinsi Papua Barat.

\section{METODOLOGI \\ Waktu dan Tempat}

Waktu penelitian berlangsung selama 1 minggu, di bulan April 2019. Penelitian ini dilakukan pada 6 bagan perahu yang berada di perairan teluk Doreri Kabupaten Manokwari, dengan 3 bagan berada di belakang Pulau Mansinam dan 3 bagan berada di sekitar perairan Anday. 
Gambar 1. Peta lokasi penelitian.

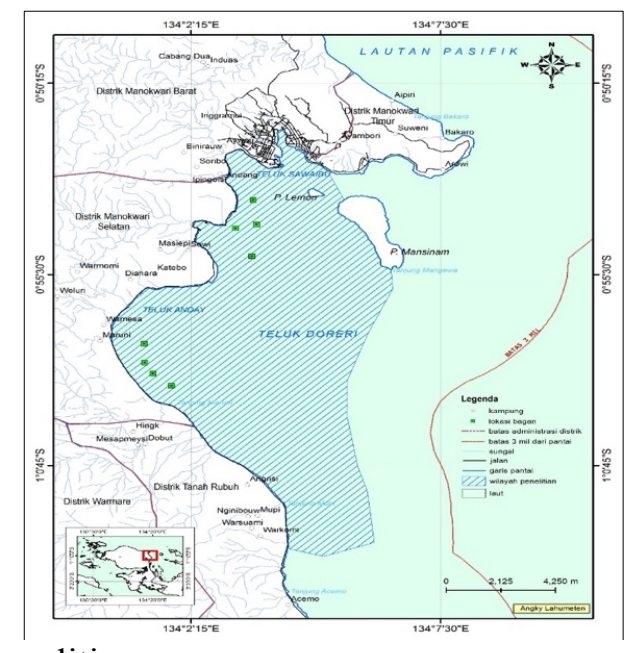

\section{Materi Penelitian}

Alat dan bahan yang dibutuhkan dan digunakan dalam menunjang pelaksanaan dan pengambilan data penelitian ini dapat dilihat pada Tabel 1 .

Tabel 1. Alat dan bahan yang digunakan.

\begin{tabular}{|c|c|c|c|c|}
\hline No & $\begin{array}{c}\text { Uraian Alat/ } \\
\text { Bahan }\end{array}$ & Spesifikasi & $\begin{array}{c}\text { Jumlah } \\
\text { Unit }\end{array}$ & Kegunaan \\
\hline 1 & Penggris & Besi $30 \mathrm{~cm}$ & 6 & Untuk mengukur panjang ikna \\
\hline 2 & $\begin{array}{c}\text { GPS (Global } \\
\text { Possition Station) }\end{array}$ & Garmin Extre 10 & 1 & $\begin{array}{c}\text { Untuk menentukan koordinat } \\
\text { Lokasi Bagan }\end{array}$ \\
\hline 3 & Bagan Perahu & $20 \times 25 \mathrm{~m}$ & 6 & Alat penangkapan ikan \\
\hline 4 & $\begin{array}{l}\text { Buku Identifikasi } \\
\text { Ikan }\end{array}$ & $\begin{array}{l}\text { ISBN-3925919-77- } \\
\text { 5/World Atlas of } \\
\text { Marine Fishes }\end{array}$ & 1 & Untuk mengidentifikasi ikan \\
\hline 5 & Camera Digital & $\begin{array}{l}\text { Canon PowerShot } \\
\text { D30 }\end{array}$ & 1 & $\begin{array}{l}\text { Mendokumentasikan } \\
\text { pelaksanaan penelitian }\end{array}$ \\
\hline 6 & $\begin{array}{c}\text { Ikan Layang } \\
\text { (Decapterus spp.) }\end{array}$ & Jenis-jenis Ikan & & Objek Penelitian \\
\hline
\end{tabular}

\section{Rancangan Penelitian}

Metode penelitian yang digunakan dalam penelitian ini adalah metode observasi. Dilakukan pengambilan data secara acak pada 6 bagan nelayan yang terdapat di 2 lokasi pengamatan. Observasi dilakukan pada 6 bagan yang berada di Perairan Teluk Doreri Kabupaten Manokwari. Penelitian ini dilakukan saat proses pengoperasian alat tangkap bagan pada bulan gelap selama 7 hari pengamatan. Data yang dikumpulkan adalah jenis-jenis hasil tangkapan ikan layang (Decapterus spp.).

\section{Prosedur Kerja}

Pengamatan dilakukan setiap hari selama 7 hari pengamatan saat pengoperasian bagan dilakukan, yaitu pukul 18.00 WIT - 
04.00 WIT. Pengamatan dilakukan pada 6 bagan yang melakukan penangkapan di Teluk Doreri, Kabupaten Manokwari yang terbagi ke dalam 2 lokasi pengamatan berdasarkan posisi letak bagan, yaitu 3 bagan yang terletak di belakang Pulau Mansinam dan 3 bagan yang terletak di sekitar perairan Anday, Kabupaten Manokwari.

Pengambilan data dilakukan setiap penarikan jaring bagan (hauling) saat nelayan bagan menarik jaring untuk mengecek hasil tangkapan. Pendataan jenis-jenis hasil tangkapan ikan layang dilakukan dengan cara menyortir ikan layang per jenisnya, kemudian di identifikasi untuk mengetahui jenis-jenis dari setiap ikan layang yang tertangkap oleh alat tangkap bagan. Proses penyortiran per jenis dilakukan untuk mempermudah proses identifikasi ikan layang. Pengamatan dan pencatatan jenisjenis ikan dilakukan setelah sudah diketahui dengan pasti untuk suatu individu jenis ikan layang berdasarkan buku identifikasi yang digunakan.

\section{Analisis Data}

Data yang terkumpul dalam penelitian ini dianalisis dengan menggunakan analisis deskriptif. Dimana data di tabulasi dan di tampilkan dalam bentuk gambar, serta di deskripsikan setiap gambar dari hasil observasi yang di dapatkan, baik hasil identifikasi jenis-jenis ikan layang, maupun hasil wawancara terkait dengan operasi penangkapan nelayan bagan di lokasi penangkapan yang berpengaruh terhadap hasil tangkapan.

\section{HASIL DAN PEMBAHASAN \\ Kondisi Umum Perairan Teluk Doreri}

Letak geografis Perairan Teluk Doreri di Kabupaten Manokwari terletak pada posisi 01-02'-15' ' LS dan 100-23'34', BT merupakan salah satu perairan yang memiliki potensi sumber daya perikanan yaitu sumber daya ikan khususnya potensi perikanan ikan layang (Depcaterus spp.). Latar belakang kehidupan nelayan di Teluk Doreri hampir sebagian merupakan bagian dari mayoritas nelayan Indonesia yang masih menggunakan peralatan tangkap sederhana. Kawasan Teluk Doreri selain sebagai fishing ground juga dimanfaatkan untuk peruntukan lain seperti, pelabuhan laut, pelabuhan perikanan dan pemukiman.

Pemanfaatan sumber daya ikan layang di daerah ini masih dilakukan dengan pengetahuan dan keterampilan yang diperoleh secara turun temurun yang belum diikuti dengan upaya pengelolaan yang memadai. Kondisi tersebut mendorong upaya pemanfaatan sumber daya ikan layang secara berkelanjutan berupa intensitas penangkapan jenis-jenis ikan di perairan pantai dengan tujuan untuk meningkatkan produksi tanpa berpikir pada kelestarian sumber daya ikan dan keberlanjutan usaha penangkapannya. Indikasi tersebut dapat diamati dari jenisjenis ikan layang (Decapterus spp.) yang tertangkap dan semakin meningkat setiap tahunnya.

\section{Sebaran Bagan di Teluk Doreri}

Bagan perahu (Boat Lift Nets) adalah salah satu jenis alat penangkapan ikan yang termasuk dalam klasifikasi jaring angkat (Lift $n e t$ ) dari jenis bagan yang digunakan nelayan untuk menangkap ikan pelagis kecil. Alat tangkap ini pertama kali diperkenalkan olah nelayan Bugis Makassar pada tahun 1950an. Bagan perahu mempunyai bentuk lebih ringan dan sederhana, dapat menggunakan satu atau dua perahu. Bagan perahu hanyut menggunakan satu perahu saja (Rusdianto, 2015).

Bagan yang melakukan pengoperasian penangkapan di Teluk Doreri berjumlah 6 bagan, dimana operasi penangkapan dilakukan selama bulan gelap. Berdasarkan hasil observasi lapang, ukuran bagan yang tersebar
Diterima/submitted:23 Mei 2019

Disetujui/accepted:28 Juni 2019 
di Teluk Doreri berbeda-beda. Ada ukuran bagan besar dan ada juga ukuran bagan kecil.

Bagan besar memiliki panjang perahu 9 meter, dengan panjang dan lebar bagan $40 \mathrm{x}$ 40 meter, sedangkan bagan kecil memiliki ukuran perahu 7 meter, dengan lebar dan panjang bagan $25 \times 25$ meter dan $30 \times 30$ meter. Besarnya ukuran bagan mempengaruhi jumlah hasil tangkapan, jenis hasil tangkapan dan lokasi penangkapan. Hal ini terkait dengan berapa kali dilakukannya penarikan jaring (hauling) dalam satu malam.

Berdasarkan hasil pengamatan di setiap bagan, untuk bagan ukuran besar biasanya melakukan hauling sebanyak 3-5 kali dalam satu kali operasi penangkapan jika hauling pertama belum mendapatkan hasil yang ditargetkan oleh nelayan bagan, sedangkan bagan ukuran kecil biasanya 2-3 kali mengangkat jaring. Hal ini dikarenakan ukuran bagan besar menggunakan mesin untuk menarik jaring pada saat hauling, sedangkan bagan ukuran kecil masih melakukan hauling dengan manual bantuan tenaga manusia (tanpa mesin penarik jaring), sehingga hasil tangkapan yang didapatkan pun berbeda.

Selain itu, sebaran bagan untuk lokasi penangkapan dari 6 bagan yang melakukan aktivitas penangkapan juga berbeda, dimana ada 2 lokasi penangkapan alat tangkap bagan di Teluk Doreri, yaitu di belakang Pulau Mansinam dan di Laut perairan Anday Kabupaten Manokwari. Hasil survei dilakukan terhadap 6 bagan tersebut, baik 3 bagan yang beroperasi di sekitar perairan Pulau Mansinam dan juga 3 bagan yang beroperasi di perairan Anday. Kebanyakan bagan besar melakukan operasi penangkapan di belakang Pulau Mansinam, sedangkan bagan ukuran kecil biasanya berlabuh di sekitar perairan Anday.

Penentuan daerah tangkapan sangat berpengaruh terhadap hasil tangkapan jenisjenis ikan layang. Salah satu faktor yang mempengaruhi keberhasilan dalam pengoperasian alat tangkap bagan perahu adalah penentuan daerah penangkapan ikan (fishing ground) dimana dalam penentuan daerah penangkapan ikan (fishing ground) dipengaruhi oleh faktor kedalaman yang berhubungan dengan jumlah hasil tangkapan.

Selain itu, jenis lampu dan banyaknya lampu pada suatu bagan juga sangat memberikan pengaruh yang besar terhadap hasil tangkapan, dimana jenis-jenis ikan seperti ikan layang merupakan jenis ikan fototaxis positif yaitu ikan yang tertarik dengan cahaya, sehingga semakin banyaknya lampu pada suatu bagan dengan ukuran bagan yang besar, maka hasil tangkapan pun lebih melimpah, dibandingkan bagan kecil dengan jumlah lampu yang sedikit. Cahaya memberikan respons positif terhadap jenisjenis ikan layang atau jenis ikan lain yang tergolong fototaxis positif di malam hari.

Sumber cahaya yang paling populer sebelum tahun 2010 adalah petromaks dengan bahan bakar minyak tanah. Namun sejak pencabutan subsidi pemerintah terhadap minyak tanah pada tahun 2010, petromaks dianggap tidak lagi ekonomis. Nelayan bagan pada kondisi ini terpaksa beralih menggunakan lampu dengan sumber energi listrik untuk menghasilkan cahaya pemikat ikan (Himam dkk., 2018). 

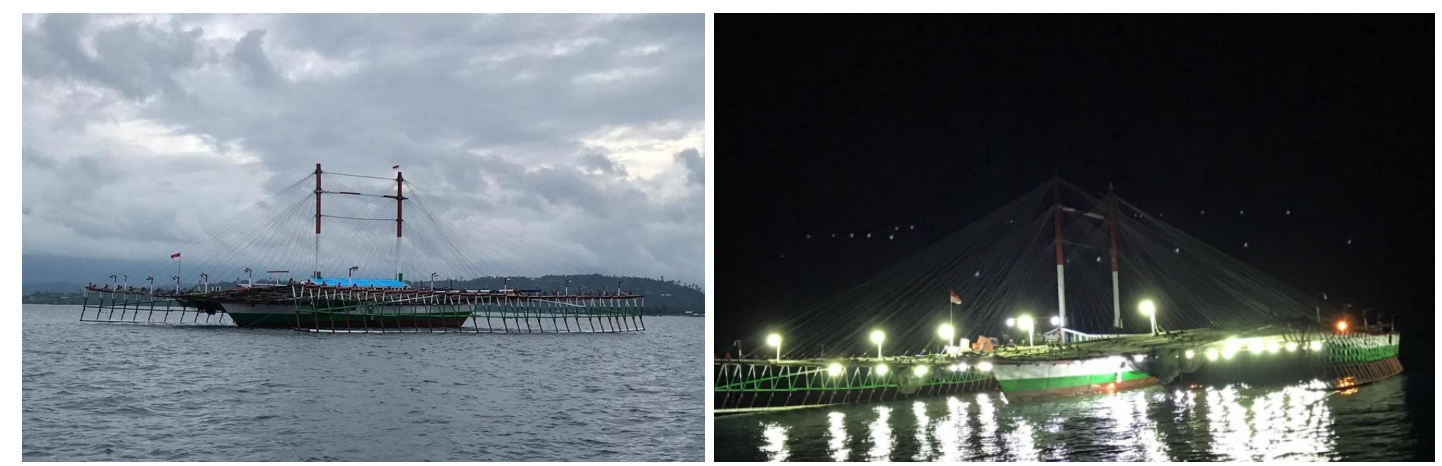

Gambar 2. Sebaran bagan di perairan Teluk Doreri.

\section{Pengoperasian Bagan di Teluk Doreri}

Salah satu yang mempengaruhi keberhasilan dalam pengoperasian alat tangkap bagan perahu adalah penentuan daerah penangkapan ikan (fishing ground) dimana dalam penentuan daerah penangkapan ikan (fishing ground) dipengaruhi oleh faktor kedalaman yang berhubungan dengan jumlah hasil tangkapan.

Berdasarkan hasil wawancara, nelayan pada perairan Teluk Doreri dalam penentuan daerah penangkapan ikan (fishing ground) hanya berpedoman pada lokasi yang biasanya menjadi tempat untuk pengoperasian alat tangkap bagan perahu seperti belakang Pulau Mansinam dan sekitar perairan Anday. Pengoperasian bagan perahu pada kedalaman perairan yang berbeda juga akan mempengaruhi hasil tangkapannya baik jumlah maupun jenisnya.

Faktor lingkungan sangat mempengaruhi banyak tidaknya jumlah hasil tangkapan seperti kedalaman perairan, semakin dalam suatu perairan maka semakin banyak juga jumlah ikan hasil tangkapan dengan asumsi bahwa semakin dalam suatu perairan, maka semakin banyak volume air yang bisa menyebabkan semakin banyak ikan yang berada di dalamnya. Hal ini berkaitan dengan pendistribusian ikan pada suatu perairan secara horizontal dan vertikal sehingga pergerakan ikan dalam habitatnya menjadi lebih luas (Purbayanto, 2004). Hal ini sama dengan hasil wawancara yang didapatkan, dimana nelayan bagan Teluk Doreri mengatakan bahwa daerah belakang Pulau Mansinam memiliki perairan yang cukup dalam, sehingga beberapa rumpon dari nelayan Tuna di pasang di belakang Pulau Mansinam sebagai patokan daerah penangkapan ikan.

Penentuan kedalaman jaring sangat tergantung terhadap jenis ikan yang ingin di tangkap, musim penangkapan dan waktu hauling, sehingga sangat dibutuhkan pengalaman dan alat bantu untuk mendeteksi keberadaan ikan di perairan seperti peralatan akustik, echosounder, dan GPS. Berdasarkan pengamatan pengoperasian bagan di Teluk Doreri, untuk bagan ukuran besar sudah menggunakan teknologi yang lebih canggih untuk menarik jaring dan mendeteksi ikan seperti mesin dalam untuk menggerakkan jaring dan akustik dan GPS untuk mendeteksi gerombolan ikan. 

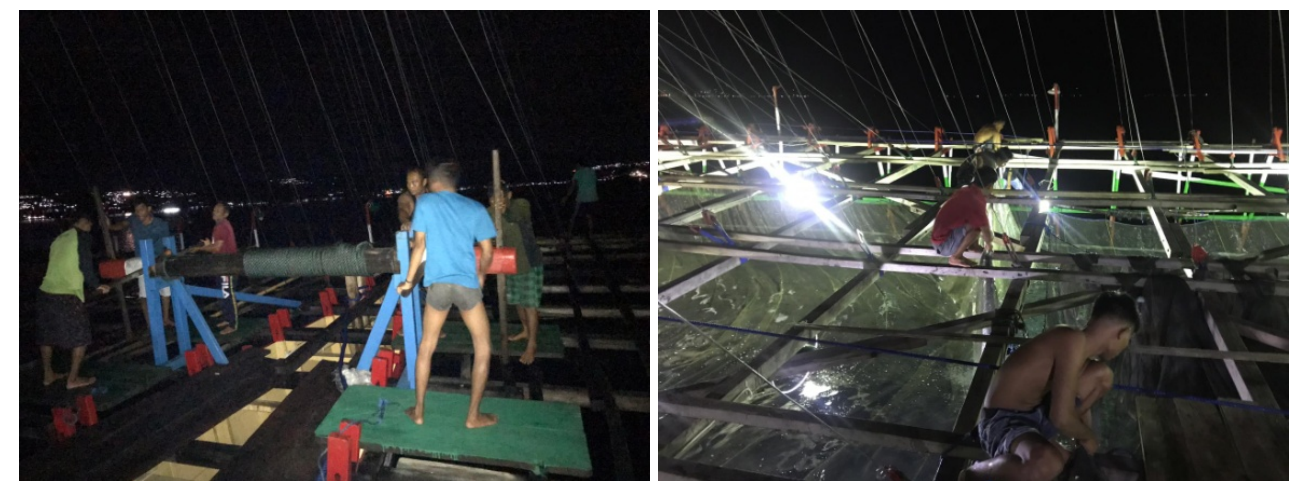

Gambar 3. Pengoperasian alat tangkap bagan.

\section{Jenis-jenis Ikan Layang yang Tertangkap oleh Nelayan Bagan di Teluk Doreri}

Dari hasil identifikasi jenis-jenis ikan layang yang tertangkap oleh nelayan bagan di Teluk Doreri, Kabupaten Manokwari, terdapat 3 jenis ikan layang, yaitu ikan layang ekor merah (Decapterus akaadsi), ikan layang ekor putih sedikit kekuningan (Decapterus macrosoma) dan ikan layang biru (Decapterus macarellus).

Hasil ini sama dengan penelitian yang dilakukan oleh Iksan dan Irham (2009), yang
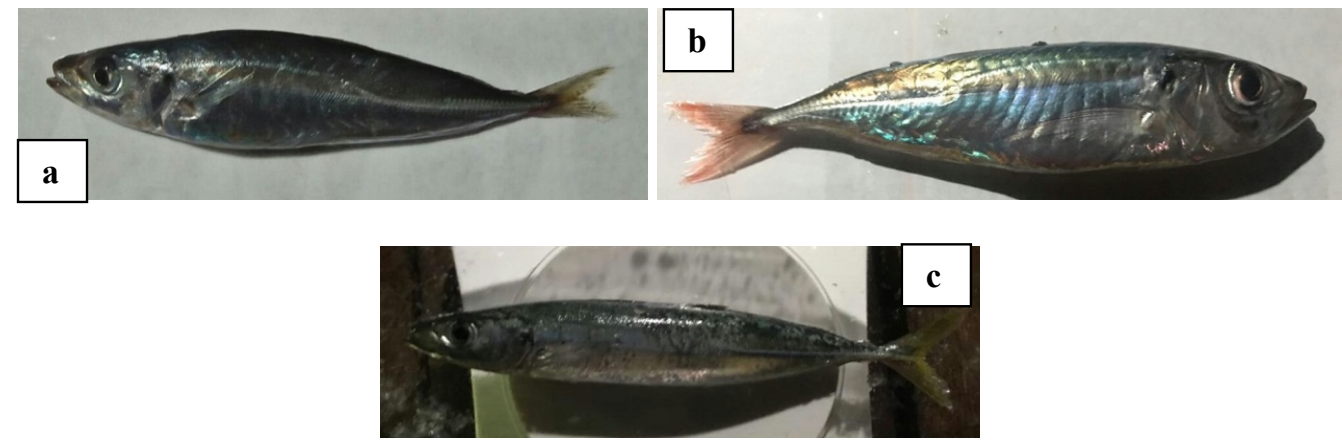

Gambar 4. Jenis-jenis ikan layang (Decapterus spp.) di perairan Teluk Doreri, (a) Decapterus macarellus, b), Decapterus akaadsi, (c) Decapterus macrosoma.

\section{KESIMPULAN DAN SARAN \\ Kesimpulan}

Berdasarkan hasil penelitian yang didapatkan, dapat disimpulkan bahwa jenisjenis ikan layang (Decapterus spp.) yang tertangkap oleh nelayan bagan di Teluk
Doreri, Kabupaten Manokwari adalah jenis Decapterus macarellus, Decapterus akaadsi, dan Decapterus macrosoma. Pada 2 lokasi penangkapan yang berbeda, yaitu di belakang Pulau Mansinam dan di sekitar perairan Anday. 


\begin{abstract}
Saran
Diperlukan penelitian lebih lanjut terkait dengan jenis-jenis hasil tangkapan ikan layang (Decapterus spp.) di perairan Teluk Doreri, Kabupaten Manokwari, sehingga dapat membantu Dinas terkait seperti Dinas Perikanan dan Kelautan, serta lembaga institusi dalam melakukan pengelolaan ikan layang berdasarkan jenis hasil tangkapan nelayan bagan, serta penelitian lanjutan dalam pengelolaan jenisjenis ikan layang secara spesies di Teluk Doreri, Kabupaten Manokwari.
\end{abstract}

\section{DAFTAR PUSTAKA}

Chan, W., Talbot and Sukhavisidhi, P., 1974. FAO species Identification sheet for fisher), Purpose Rome 1.

Himam, M.I., Mawardi W, Diniah dan Zulkarnain, 2018. Efektivitas Lampu Led Celup sebagai Lampu Hauling pada Bagan Perahu (Effectiveness of Submersible LED Light as Hauling Lamp on Boat Liftnet). Albacore, 2(1), Hal.069-077.

Iksan, K.H., dan Irham, 2009. Pertumbuhan dan Reproduksi Ikan Layang Biru (Decapterus macarellus) di Perairan Maluku Utara (Growth and reproduction of mackerel scads, Decapterus macarellus (Cuvier, 1833) in North Moluccas waters). Jurnal Iktiologi Indonesia, 9(2), hal, 163-174.

Munro, I.S.R., 1955. The marine and fresh water fishes of Ceylon. Department of external All airs. Canberra: pp.351.

Munro, I.S.R., 1967. The jished New Guinea. Department of Agriculture. Std and Fisheries, Port Moresby. New Guinea. pp. 651 .

Purbayanto, 2004. Performa Selektivitas Alat Tangkap Bagan Rambo di Perairan Barru Selat Makasar. Penelitian Perikanan Makasar 10:24-30.

Rusdianto, 2015. Hubungan Hasil
Tangkapan pada Bagan Tancap Dengan Menggunakan Lampu Celum Bawah Air dan Lampu Petromaks Di Perairan Pulau Beras Basah Kotamadya Bontang, 4(1), p.39.

Smith, I.L.B., 1950. The sea fishes of Southern Africa. Cape Times Limites, Cape Town. pp. 550.

Weber, M., dan De Beaufort, L.F., 1931. The fishes of the Indo-Australian Archipelago. E.J. Leiden, 6: p.194-201. 